\title{
Restored and De-Restored: Killing off Garrick in John Philip Kemble's King Lear
}

Filip Krajník

\begin{abstract}
Nahum Tate's Restoration version of King Lear (1680 or 1681) managed to replace Shakespeare's original on English stages for more than a century and a half. While the efforts of David Garick and George Colman to reinstate Shakespeare's plot and language in English theatres in the latter half of the eighteenth century have been acknowledged, little has been said in this respect about the late eighteenth-century actor and theatre manager John Philip Kemble and his version of the play that premiered in 1792. The present article will try to propose the possible motivation of Kemble's step to discard Garrick's popular alteration and will also argue that the decision to erase Garrick's restorations and recur essentially to Tate's outmoded version of the play at the end of the eighteenth century was probably one of the factors that helped to restore Shakespeare's original in English theatres when King Lear was revived in the 1820s after a decade-long hiatus.
\end{abstract}

\section{Keywords}

William Shakespeare, King Lear, adaptation of Shakespeare, Restoration theatre, eighteenth century English theatre, Nahum Tate, George Colman, David Garrick, John Philip Kemble

This article was supported by the Czech Science Foundation project GA19-07494S. English Theatre Culture 1660-1737. 
The late 1680 or early 1681 adaptation of King Lear by Nahum Tate is a frequently quoted example of the Restoration's treatment of Shakespeare's dramatic works, and Tate's description of the original Shakespeare play as "a Heap of Jewels, unstrung and unpolisht $[\ldots]$ wanting in the Regularity and Probability" has become notorious (TATE 1681: A2v $)$. Equally famous is the much celebrated 1838 production of King Lear by William Macready at Covent Garden, which, after more than a century and a half, completely restored Shakespeare's version of the play on English stages and in many respects laid the foundations of our current understanding of the work (see MULLIN 2010).

The ultimate revival of Shakespeare's original in English theatres has been traditionally considered within the context of David Garrick's continuous efforts to restore portions of Shakespeare's King Lear at Drury Lane Theatre throughout the eighteenth century and - albeit less so - in the context of Garrick's colleague and later rival George Colman's own version of the play blending Tate and Shakespeare, staged in 1768 at Covent Garden. In contrast, the possible role of actor and theatre manager John Philip Kemble (who took over Garrick's former role at Drury Lane in the late 1780s) in the process of reinstating Shakespeare's King Lear on English stages has sunk into obscurity. The present article will argue that Kemble's controversial decision to revert essentially to Tate's version of the play at the end of the eighteenth century was probably one of the factors that helped to restore Shakespeare's original on the English stage when King Lear was revived in Britain in the 1820s after a decade-long hiatus.

Throughout his career, actor, director, theatre manager and the biggest theatre celebrity of eighteenth-century England David Garrick (1717-1779) was carefully building his own reputation as "the eighteenth century's definitive embodiment of Shakespeare" and "the true son of Shakespeare's royal ghost" (DOBSON 1992: 14). Whether his devotion to Shakespeare was genuine or more of a professional strategy, as Vanessa Cunningham speculates (2008: 5), is a question beyond the remit of the present study. It is certain, however, that Garrick's stardom was largely dependent on Shakespeare and Shakespeare's status as a national poet. Of all the Shakespearean roles that Garrick played in the course of his career (Benedick, Hamlet, King Lear, Richard III, Romeo, Posthumus, Leontes and others), King Lear held special significance: it was his first role at Drury Lane in 1742 (at the age of 25), a theatre of which he later became the manager for almost thirty years, and also his last Shakespearean role before his retirement in 1776.

It seems that King Lear especially attracted Garrick because its eponymous main character offered the actor a great opportunity fully to employ his art. Garrick's acting style, very modern and distinctive at the time, involved a range of techniques, including paying attention to physical detail, employing a wide variety of facial expressions to convey emotions and their sudden changes, subtle pantomimic gestures and employment of a non-declamatory voice that preferred sense to poetic rhythm (see WOO 2008: 22-27). The ancient king, whose fits of anger, both physical and psychological suffering, mental decay and ultimate coming to his senses make him stand out even within the repertoire of Shakespeare's tragic heroes, seemed an ideal role for an actor 
of Garrick's kind. Indeed, Lear became Garrick's signature role and the audience frequently gave him "applause beyond description" and cried "Garrick for Ever" (PEDICORD and BERGMANN 1981: 444). After one production of the play, the Scottish biographer and lawyer James Boswell wrote in his diary: "I was fully moved, and I shed abundance of tears" (qtd. in BURNIM 1961: 141).

As Cunningham observes, while Garrick might have been gradually replacing Tate's language with Shakespeare's original from the 1750s onwards, his primary interest seems to have been to create space for himself to excel in the titular role. Indeed, the only restorations of Shakespeare's lines in the promptbook for the 28 October 1756 production of the play (TATE 1756), announced as "With Restorations from Shakespear" (CUNNINGHAM 2008: 120), are two brief passages from the end of Act 1 when Lear is rejected by both of his daughters - a point when his mental health starts deteriorating rapidly, therefore offering Garrick a chance to show off his acting talent. The true impulse for more extensive incorporation of Shakespeare's original was probably the aforementioned partial restoration by George Colman (1732-1794) (HARRIS 1971; cf. CUNNINGHAM 2008: 121-123), which not only was much closer to Shakespeare's arrangement and language, but also jettisoned Tate's love subplot between Cordelia and Edgar, and likely even restored Shakespeare's tragic ending. ${ }^{1}$ Compared to Colman's version, Garrick's restoration, published in 1773, was very conservative. In short, Garrick approached the task as a theatre manager rather than a bardolator, and at least one of his ambitions was to create a text that would suit his own acting skills and style.

When John Philip Kemble (1757-1823), the then rising acting star of the provinces (chiefly York and Dublin), was brought to London by the proprietors of Drury Lane Theatre in 1783, one of the issues he had to deal with during his time with the company was the ghost of Garrick's reputation. Unlike Garrick, whose "character" acting was based on detail and emotion, Kemble preferred "archetypal" acting, focusing on "lofty, grand, abstract, and universal aspects of the characters he played, rather than the minute idiosyncratic details that would mark them as unique" (WOO 2008: 53). He was also fond of extravagant, lavish scenery, presenting Shakespeare as a timeless, national dramatist. Charles H. Shattuck points out that this style was particularly wellsuited to Shakespeare's Roman plays; not so much, however, to character plays such as King Lear (SHATTUCK 1974: x).

The first time that Kemble played the iconic role was on 21 January 1788, with his sister, the much celebrated Shakespearean actress Sarah Siddons (who was, in fact, two years older than Kemble), as Cordelia. The fact that the version produced was the one that Garrick had adapted for himself surely invited comparison between the two actors, especially for those who would still remember Garrick's farewell to his favourite role

1 Although, in the printed edition of his text, Colman asserted that "[t]o reconcile the catastrophe of Tate to the story of Shakespeare, was the first grand object which I proposed to myself in this alteration" (1768: iv), at least two contemporaneous witnesses explicitly mentioned that Colman "restored the original distressed catastrophe [...] a circumstance not greatly in favour of humanity or delicacy of feeling" (qtd. in ODELL 1920a: 381). 
some twelve years earlier. In terms of money raised by ticket sales, the production was a great success (which might have been caused by the fact that King Lear had not been produced by Drury Lane since 1779); for Kemble himself, however, it appears to have been less so. According to James Boaden, "[t]he performance was hailed with delight by many of Mr. Garrick's friends"; Boaden, however, also hastened to add that "in a few points, there was no inferiority; as a whole, nothing ever approached the influence of Garrick in this [...] greatly superior dramatic character to Hamlet, to Macbeth, to Othello" (BOADEN 1825: 379). Even less flatteringly, Sir Walter Scott admitted that Kemble was "not more than the equal of Garrick" as Hamlet, "as yet unapproachable" as Macbeth, but as Lear, "decidedly inferior to Garrick" (SCOTT 1826: 218). Since the production was supposed to be a showcase for Kemble in the role that was considered the mark of a competent Shakespearean actor (see BOADEN 1831: 234), such assessments must have been disappointing for him - especially considering the fact that Kemble was known to have somewhat unrealistic ideas about his own acting abilities (see SHATTUCK 1974: x).

When Kemble assumed the office of acting manager of Drury Lane later that year, King Lear disappeared from the theatre's repertoire, while a number of English classic plays were staged with Kemble in a leading role (among others, Kemble appeared as Richard III, Macbeth, Romeo, Shylock and Cardinal Wolsey in 1788/89 and Henry V in the following season). When the play was revived again in 1792, Kemble took a surprising step and resorted to Tate's more than century-old version, with only a handful of small changes. What motivated Kemble to commit "this act of theatrical vandalism", as George C. D. Owell (1920b: 55) has called this decision? Although Kemble did not preface the printed edition of his text with any explanatory notes that would justify this choice, two possible answers suggest themselves:

(1) Tate's King Lear - if criticised for a number of reasons at least since the beginning of the eighteenth century ${ }^{2}$ - offered a more straightforward version of the play for both the producers and the audiences; Garrick's success with this text half a century earlier and his general reluctance to alter significantly "a proven audience-pleaser" testify to the stage potential of Tate's piece (CUNNINGHAM 2008: 120). It is perfectly conceivable that Kemble wanted to try the Shakespearean flagship role with a version of the play that might better suit his acting style and his vision of the character.

(2) Kemble was simply annoyed by being constantly compared to his more popular - and, in the eyes of many, more talented - predecessor and wanted to emancipate himself from Garrick's legacy. To do this, it would have made sense for him to deploy a text that was not so closely associated with Garrick's name.

Although we are now venturing into the realm of speculation, there are indications that argue for the second of the options. While Kemble's text incorporates no more

2 In the 16 April 1711 issue of The Spectator, Joseph Addison maintained that "King Lear is an admirable Tragedy [...] as Shakespeare wrote it; but as it is reformed according to the chymerical Notion of poetical Justice, in my humble Opinion it has lost half of its Beauty" (ADDISON 1987: 170). 
than a few dozen lines from Shakespeare's original (none directly related to the delineation of Lear's character), ${ }^{3}$ it contains two significant omissions from Tate's text. The first one is at the end of Act 3. After being blinded by Cornwall and Regan, Gloster ${ }^{4}$ in Tate's version pronounces a soliloquy informing the audience that

with these bleeding Rings

I will present me to the pittying Crowd,

And with the Rhetorick of these dropping Veins

Enflame 'em to Revenge their King and me. (TATE 1681: F4')

This speech, showing an arguably less shattered and more active Gloster than we know from Shakespeare, is preserved by Garrick, but omitted by both Colman and Kemble. A second, more subtle cut can be found in the following act, in the scene when Edgar convinces Gloster, in order to cure him from his despair, that he (Gloster) has miraculously survived a jump from a cliff at Dover. Tate incorporates this famous situation into his version and so does Garrick in his partial restoration. Colman, however, had strong objections against the motif, which he expressed in the preface to his text:

“The utter improbability of Glocester's imagining, though blind, that he had leaped down Dover Cliff" has been justly censured by Dr. Warton; and in the representation it is still more liable to objection than in print. I have therefore, without scruple, omitted it, preserving, however, at the same time, that celebrated description of the Cliff in the mouth of Edgar. (COLMAN 1768: $\mathrm{A} 3^{\mathrm{v}}-\mathrm{A} 4^{\mathrm{r}}$ )

In his version, when Glocester is ready to jump, the action is interrupted by the entrance of the mad Lear:

Glo. O you mighty Gods!

This world do I renounce; and in your sights

Shake patiently my great affliction off:

If I could bear it longer, and not fall

To quarrel with your great opposeless wills,

My snuff and latter part of nature should

Burn itself out. If Edgar live, O bless him!

Enter Lear, drest madly with flowers.

3 These are passages in Act 1, Scene 3 (according to Kemble's division) in Lear's dialogue with Kent in disguise; in Act 2, Scene 1, showing Edmund pretending to Gloster that Edgar wounded him; and Act 5, Scene 4, with Edmund wishing that Lear and Cordelia be rescued. All these can also be found in both Colman and Garrick's restorations.

4 I am using the spelling of the name as it appears in the version currently in question. While in Shakespeare, the name is usually normalised as "Gloucester", Tate, Garrick and Kemble have "Gloster", while Colman uses the form "Glocester". 

Lear. No, they cannot touch me for coyning:
I am the King himself.
Glo.
Ha! Who comes here? (COLMAN 1768: E3 ${ }^{\text {) }}$

In a rare instance of diverging from Tate, Kemble decided to follow Colman's sentiment and, with small differences, made the same alteration with a very similar result:

\author{
Glo. [Kneels.] Thus, mighty gods, this world I do renounce, \\ And in your sight shake my afflictions off: \\ If I could bear them longer, and not fall \\ To quarrel with your great opposeless wills, \\ My snuff and feebler part of nature should \\ Burn itself out. If Edgar live, O, bless him! \\ Now, fellow, fare thee well. \\ Edg. Hold. - Who comes here? \\ Enter King Lear, a coronet of flowers on his head, $\mathcal{E}^{2}$. \\ Lear. No, no; they cannot touch me for coining; \\ I am the King himself. (KEMBLE 1808: $\mathrm{E}^{\mathrm{r}-\mathrm{v}}$; the stage direction is original)
}

In the context of Kemble's changes, it is noteworthy that the 1773 edition of Garrick's King Lear was accompanied by an endorsement from Francis Gentleman, an Irish dramatic writer and critic, who maintained that "[t]his play, in its present state, will, we doubt not, while any taste for the drama remains, continue to gain advantage and applause in public, while in private it must give very considerable pleasure" (GARRICK 1773: H4v). Earlier, Gentleman had explicitly called Garrick's King Lear "more nervous than that by the Laureat [i.e., Tate]; and much more agreeable than Mr. Colman's late alternation" (GARRICK 1773: B2 ${ }^{\mathrm{r}}$ ). Is it possible that, by sidelining Garrick's version and returning to Tate with some ostensibly Colman-esque touches (Colman was still alive in 1792 and could have theoretically seen the production), Kemble primarily wanted to prove wrong the critics who praised his predecessor's achievements and neglected his? A certain bitterness towards Garrick might indeed be illustrated by Kemble's personal notes on the history of English theatre deposited at the Folger Shakespeare Library. Herschel Baker observes that "[s]ome of his [i.e., Kemble's] more illustrious predecessors are dismissed with most perfunctory notices”, including Garrick, about whom Kemble merely wrote: “'David Garrick, born at Hereford 1716 [sic] \& was buried in Westminster Abbey'" (BAKER 1942: 216; the [sic] is Baker's: Garrick was in fact born in 1717).

Whatever Kemble's true motives to "de-restore" Shakespeare's text at the end of the eighteenth century were, the truth remains that his version was only rarely staged down to 1810, when King Lear was banned because of King George III's encroaching madness. It appears, however, that not even Tate's text managed to improve the overall impression of Kemble's Lear. In the 22 May 1808 issue of The Examiner, Leigh Hunt described Kemble's performance in a recent production of the play as follows: 
He personated the king's majesty perfectly. But not the king's madness. [...] [H]e is always stiff, always precise, and he will never, as long as he lives, be able to act any thing mad unless it be a melancholy mad statue. (HUNT 2003: 60)

By the time the ban on the play was lifted after King George's death in 1820, Kemble would have retired from the theatre, his last public appearance having been the titular Caius Marcius in Shakespeare's Coriolanus at Covent Garden on 23 June 1817. In the meantime, however, his version of King Lear was reprinted several times and, by the early nineteenth century, Garrick's hybrid text had been in the minds of both theatregoers and readers largely replaced by the slightly modified late seventeenth-century adaptation. When, in the first decades of the nineteenth century, critical voices such as Hunt's started calling for a restoration of Shakespeare's original version of King Lear once again, they attacked not Garrick, whose versions of Shakespeare were sometimes still staged well into the late nineteenth century, ${ }^{5}$ but the outmoded Nahum Tate. The aforementioned review by Hunt harshly criticised Tate's treatment of King Lear, arguing that

a mere rhymer, whose dullness has become proverbial, should create whole scenes of his own and adorn them with a few extracts from Shakespeare, that he should turn the current of our poet's feeling into scanty sprinklings over his own barren fancy and then cry out, "How fertile I am!” - is really a violation of a man's literary property. (HUNT 2003: 56)

While additional factors were instrumental in the restoration of Shakespeare's version of King Lear in early nineteenth century (see MULLIN 2010: 21-22), Kemble's return to Tate at the end of the eighteenth surely accelerated the process. Without Kemble's controversial - and perhaps somewhat childish - decision to erase the Learean achievement of his predecessor, it is conceivable that entire generations of nineteenthcentury English audiences might have enjoyed some form of a Shakespeare/Garrick hybrid of the play, ${ }^{6}$ and the original Shakespearean text would have had to wait for several more decades for its full rehabilitation.

5 As Marsden points out, Garrick's adaptation of The Taming of the Shrew, entitled Catherine and Petruchio, was regularly staged until 1887 and elements of his adaptation of Romeo and Juliet were eliminated as late as 1884 (MARSDEN 1995: 1).

6 After all, the 1786 edition of Garrick's King Lear with further restorations from Shakespeare (GARRICK 1786) indicates that even after the 1773 Bell edition of the play, either Garrick himself or someone else in the theatre continued to alter the text, cutting Tate and inserting more Shakespearean material (see CUNNINGHAM 2008: 129-133). 


\section{Bibliography}

ADDISON, Joseph. 1987 [1711]. No. 40, Monday, April 16, 1711. The Spectator, vol. I. Oxford: Clarendon Press, 1987: 168-173.

BAKER, Hershel. 1942. John Philip Kemble: The Actor in His Theatre. Cambridge, MA: Harvard University Press, 1942.

BOADEN, James. 1825. Memoirs of the Life of John Philip Kemble. vol. I. London: printed for Longman, Hurst, Rees, Orme, Brown and Green, 1825.

BOADEN, James. 1831. Memoirs of Mrs. Siddons Interspersed with Anecdotes of Authors and Actors. $2^{\text {nd }}$ ed., vol. II. London: Henry Colburn and Richard Bentley, 1831.

BURNIM, Kalman A. 1961. David Garrick, Director. Carbondale: Southern Illinois University Press, 1961.

[COLMAN, George]. 1768. The History of King Lear. London: printed for R. Baldwin and T. Becket, 1768.

CUNNINGHAM, Vanessa. 2008. Shakespeare and Garrick. Cambridge: Cambridge University Press, 2008.

DOBSON, Michael. 1992. The Making of the National Poet: Shakespeare, Adaptation and Authorship, 1660-1769. Oxford: Oxford University Press, 1992.

[GARRICK, David]. 1773. King Lear, A Tragedy, by Shakespeare. London: John Bell, 1773.

GARRICK, David. 1786. King Lear, A Tragedy: Altered from Shakespeare. London: printed for C. Bathurst etc., 1786.

HARRIS, Arthur John. Garrick, Colman, and King Lear: A Reconsideration. Shakespeare Quarterly 22 (1971): 1: 57-66.

HUNT, Leigh. 2003 [1808]. Theatrical Examiner, No. 18. The Selected Writings of Leigh Hunt, vol. I: Periodical Essays, 1805-14. Greg KUCICH and Jeffrey N. COX (eds.). London: Pickering and Chatto, 2003: 56-60.

KEMBLE, J[ohn] P[hilip]. 1808. Shakespeare's King Lear (from Nahum Tate's Alterations). London: printed for the Theatre [Royal in Covent Garden], 1808.

MARSDEN, Jean I. 1995. The Re-Imagined Text: Shakespeare, Adaptation, and Eighteenth-Century Literary Theory. Lexington: The University Press of Kentucky, 1995.

MULLIN, Emily. 2010. Macready's Triumph: The Restoration of King Lear to the British Stage. Penn History Review 18 (2010): 1: 17-35.

ODELL, George C. D. 1920a. Shakespeare from Betterton to Irving. vol. I. New York: Charles Scribner's Sons, 1920.

ODELL, George C. D. 1920b. Shakespeare from Betterton to Irving. vol. II. New York: Charles Scribner's Sons, 1920.

PEDICORD, Harry William and Frederick Louis BERGMANN (eds.). 1981. The Plays of David Garrick, vol. III: Garrick's Adaptations of Shakespeare, 1744-1756. Carbondale: Southern Illinois University Press, 1981.

SCOTT, Walter. 1826. Life of John Philip Kemble. Quarterly Review 34 (1826): 196-248.

SHATTUCK, Charles H. 1974. General Introduction. In id. John Philip Kemble Promptbooks. vol. I. Charlottesville: University Press of Virginia for the Folger Shakespeare Library, 1974: ix-xxi.

TATE, N[ahum]. 1681. The History of King Lear. London: printed for E. Flesher, 1681.

TATE, N[ahum]. 1756. The History of King Lear. London: printed for C. Hitch and L. Hawes etc., 1756. British Library, General Reference Collection C.119.dd.22.

WOO, Celestine. 2008. Romantic Actors and Bardolatry: Performing Shakespeare from Garrick to Kean. New York: Peter Lang, 2008. 


\section{Mgr. Filip Krajník, PhD.}

Department of English and American Studies, Faculty of Arts, Masaryk University Brno, Arna Nováka 1, Brno 602 00, Czech Republic filip.krajnik@phil.muni.cz

Filip Krajník is a lecturer in English literature at the Department of English and American Studies, Faculty of Arts, Masaryk University in Brno, Czech Republic. His main research interests are late medieval English poetry and early modern English theatre. At the moment, he is co-editing a volume on medieval female piety entitled Women Across Borders (forthcoming 2021). He is the principal investigator of the Czech Science Foundation project GA19-07494S. English Theatre Culture 1660-1737; an edited volume, tentatively entitled Forms, Identities and Inspirations in Restoration Theatre, is expected in 2022. 